\title{
Web-Base Information System of Rice Milling Places In Malind District
}

\author{
Stanly Hence Dolfi Loppies", Hasanudin Jayawardana, Kiki Resmi Hadi Santoso \\ Department of Information System, Faculty of Engineering, Universitas Musamus, Merauke 99600, Indonesia
}

\begin{abstract}
Rice is a strategic food commodity that can affect the lives of all Indonesian citizens and is given top priority from the government to achieve national food security. Malind district is an agricultural area with quite extensive rice plants covering an area of $551.24 \mathrm{~km}^{2}$ with eight villages, and the number of rices milling places as many as fourteen places. The milling places play a very real role in advancing the economy nationally. Farmers in Malind District have problems finding and obtaining information from mills when grinding their unhulled rice. Website contains information that can be accessed easily and quickly using an address or link from an information system.
\end{abstract}

Keywords: Rice milling places, Website

\section{Introduction}

Rice is a strategic food commodity that can affect the lives of all Indonesian citizens and is given top priority from the government to achieve national food security [1]. Malind district is an agricultural area with quite extensive rice plants covering an area of $551.24 \mathrm{~km}^{2}$ with a population of 10062 people spread over eight villages. Based on field observations, the number of people who work as farmers is 3120 people. In one harvest season the farmers can produce at least 2.5 - 5 tons of unhulled rice per farmer. The total of rice milling places in the Malind district are fourteen. five milling places in Kumbe village, five in Rawasari village and four in the Sukamaju village. The storage quota for each mill varies depending on the type of milling machine used and the size of the warehouse [2]. A mill is a food production infrastructure that plays a vital role in stabilizing the economy of the people and the country [3].

The process for farmers in Malind district to obtain information on grain stock quotas and milling operational costs is to visit a rice mill to register the unhulled rice they want to grind. The mill will check the remaining stock of unhulled rice in the warehouse, if the grain stock to be milled exceeds the maximum capacity quota, the mill will confirm to the farmers that grain milling cannot be carried out or postponed until the amount of stored stock decreases. However, if the stored stock is still in sufficient quota to match the operational costs offered, the unhulled rice will be taken immediately and immediately milled. This proves that there is no information facility that can help farmers to grind their unhulled rice more quickly, because the milling business management has not been supported by the use of information technology.

A website is a online media that is interconnected and can be accessed using a web browser that requires the internet [4]. Website contains information that can be accessed easily and quickly using an address or link from an information system [5].

Electronic information systems are a series of electronic devices and procedures that serve to prepare, collect, process, analyze, store, display, announce, transmit and / or disseminate information that has meaning or can be understood by people who are able to understand it [6].

\section{Theoretical Review}

\subsection{Electronic information system}

A series of electronic devices and procedures that serve to prepare, collect, process, analyze, store, display, announce, transmit, and / or disseminate information that has meaning or can be understood by people who are able to understand it [6]. Electronic Information is one or a set of electronic data, including but not limited to writing, voice, image, map, draft, photo, electronic data interchange, electronic mail, telegram, telex, telecopy or the like, letters, signs, numbers, Access Codes, symbols, or processed perforations that have meaning or can be understood by people who are able to understand them $[4,6]$ Technical and management information systems are the embodiment of the application of information technology products into a form of organization and management in accordance

\footnotetext{
* Corresponding author : stanly@unmus.ac.id
} 
with the characteristics of the needs of the organization and in accordance with its intended purposes. [7, 8].

\subsection{Internet}

The internet is a connections and communication of large and small computer networks, the compters interconnected using communication (tele) networks that exist throughout the world [9]. All the peoples who actively participating, so that the internet becomes a valuable fast informations update resource [10].

\subsection{Website}

A website is a web page that is interconnected and can be accessed using a web browser that requires the internet [11]. a web browser is a tool used to explore information on the internet network from a medium such as websites, blogs, social networks, etc [12]. which are stored on the internet. web is an application that contains multimedia documents such as text, images, sound, animation, video in it that uses the HTTP protocol (hypertext transfer protocol) as an intermediary medium in accessing it [10].

\subsection{Likert Scale}

Likert scale respondent indicates degree of agreement and disagreement with a variety of statements about some attitude, object, person or event [13]. Likert scale dimensions are measured and translated from variables, from dimensions to indicators and from indicators to be translated into measurable subindicators [9]. Likert scale is also most widely used for measuring instrument in information system as well. Usually provided five scale options with formats such as [13]:
a. Strongly Agree
b. Agree
c. I quite Agree
d. Don't Agree
e. Strongly Disagree

\section{Design}

\subsection{Conceptual design}

The conceptual design is used in order to see the flow of the system to be built. The conceptual form of the design of the rice milling information system in the Malind district can be shown by the flowchart in Fig 1 .

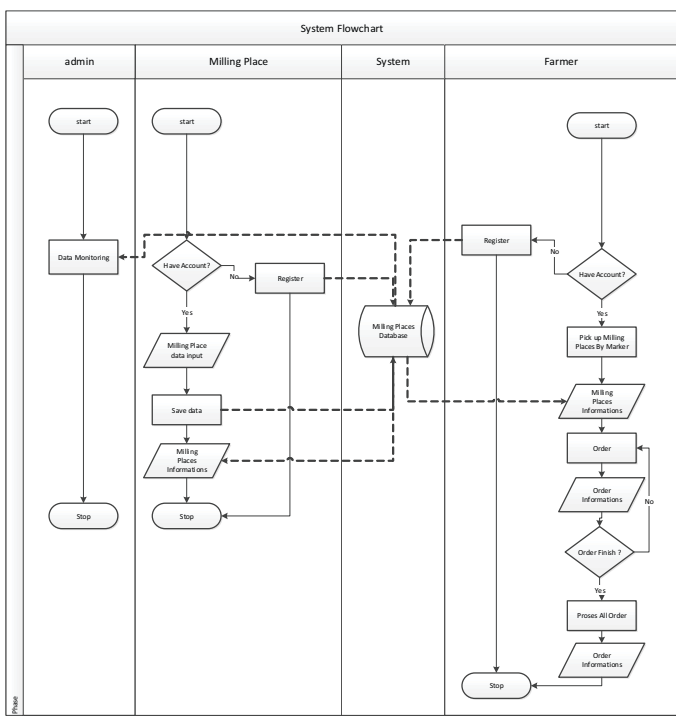

Fig. 1. Flowchart System.

\subsection{Database design}

The database design of the rice milling places information system is shown in Fig 2.

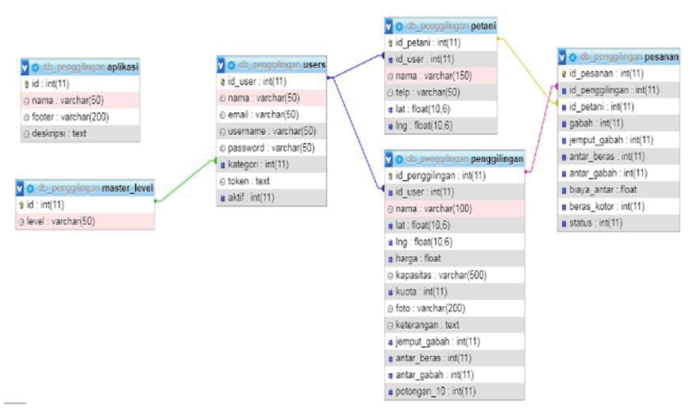

Fig. 2. Database design

\section{Result}

The results obtained from this study is a website-based information system application for rice milling places in the Malind district. With an attractive appearance, it is easy enough for farmers to use to find and obtain information where they will grind the paddy at a clear cost and the milled grain is finished on time, as well as clear proof of transaction

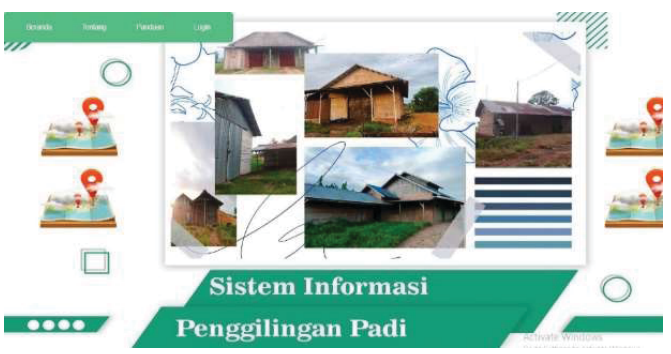

Fig. 3. Home Interface 
Table 1.1. Results of the questionnaire from milling

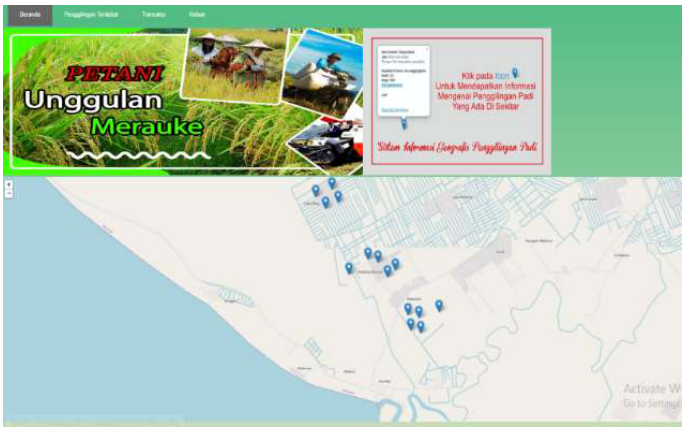

Fig. 4. Main menu interface for farmer

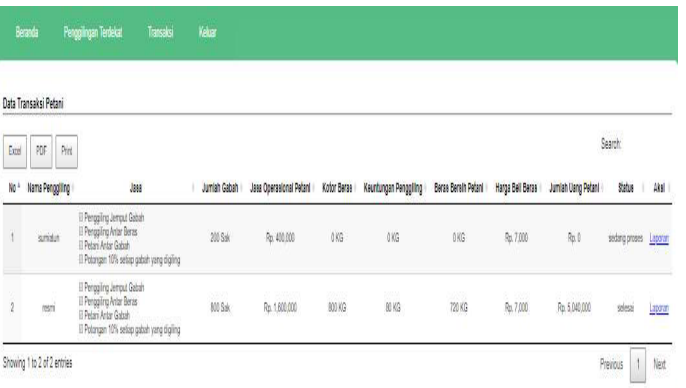

Fig. 5. Information transaction form



Fig. 6. Graph of the rice milling statement

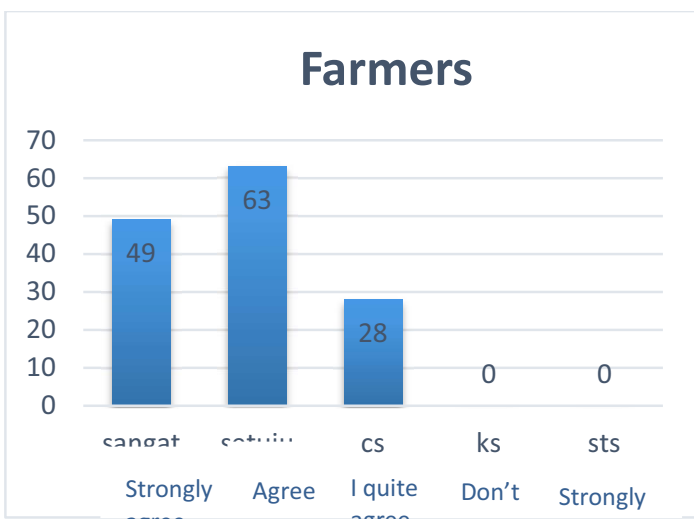

Fig. 7. Graph of the farmer statement

\begin{tabular}{|l|c|c|}
\hline \multicolumn{1}{|c|}{ Statement } & $\begin{array}{c}\text { Criterium } \\
\text { Score }\end{array}$ & $\begin{array}{c}\text { Answer } \\
\text { Scale }\end{array}$ \\
\hline $\begin{array}{l}\text { The system that has been } \\
\text { created has an attractive } \\
\text { interface! }\end{array}$ & $91.4 \%$ & $\begin{array}{c}\text { Strongly } \\
\text { Agree }\end{array}$ \\
\hline $\begin{array}{l}\text { The system that has been } \\
\text { created has menus that are } \\
\text { easy to understand! }\end{array}$ & $82.2 \%$ & $\begin{array}{c}\text { Strongly } \\
\text { Agree }\end{array}$ \\
\hline $\begin{array}{l}\text { The system that has been } \\
\text { created can be easily } \\
\text { used by user! }\end{array}$ & $77.1 \%$ & Agree \\
\hline $\begin{array}{l}\text { The system that has been } \\
\text { created can calculate the } \\
\text { milling profit! }\end{array}$ & $77.1 \%$ & Agree \\
\hline $\begin{array}{l}\text { The system that has been } \\
\text { made supports milling } \\
\text { performance! }\end{array}$ & $72.8 \%$ & Agree \\
\hline $\begin{array}{l}\text { The system that has been } \\
\text { created } \\
\text { information and the } \\
\text { location of the milling! }\end{array}$ & $72.8 \%$ & Agree \\
\hline $\begin{array}{l}\text { Proof of transaction } \\
\text { activity made by the } \\
\text { system is in accordance } \\
\text { with what the milling } \\
\text { wants! }\end{array}$ & $72.8 \%$ & Agree \\
\hline
\end{tabular}

Table 1.2. Results of the questionnaire from farmers

\begin{tabular}{|l|c|c|}
\hline \multicolumn{1}{|c|}{ Statement } & $\begin{array}{c}\text { Criterium } \\
\text { Score }\end{array}$ & $\begin{array}{c}\text { Answer } \\
\text { Scale }\end{array}$ \\
\hline $\begin{array}{l}\text { The system that has been } \\
\text { created has an attractive } \\
\text { interface! }\end{array}$ & $91 \%$ & $\begin{array}{c}\text { Strongly } \\
\text { Agree }\end{array}$ \\
\hline $\begin{array}{l}\text { The system that has been } \\
\text { created has menus that are } \\
\text { easy to understand! }\end{array}$ & $85 \%$ & $\begin{array}{c}\text { Strongly } \\
\text { Agree }\end{array}$ \\
\hline $\begin{array}{l}\text { The system that has been } \\
\text { created can search for } \\
\text { milling locations and } \\
\text { information! }\end{array}$ & $82 \%$ & $\begin{array}{c}\text { Strongly } \\
\text { Agree }\end{array}$ \\
\hline $\begin{array}{l}\text { The system that has been } \\
\text { created can calculate the } \\
\text { costs to be incurred! }\end{array}$ & $99 \%$ & $\begin{array}{c}\text { Strongly } \\
\text { Agree }\end{array}$ \\
\hline $\begin{array}{l}\text { The system that has been } \\
\text { created can print } \\
\text { transaction reports! }\end{array}$ & $81 \%$ & Strongly \\
\hline $\begin{array}{l}\text { The system that has been } \\
\text { created increases the } \\
\text { efficiency of time in } \\
\text { searching and selecting } \\
\text { a milling! }\end{array}$ & $81 \%$ & Agree \\
\hline $\begin{array}{l}\text { Proof of transaction } \\
\text { activity made by the } \\
\text { system is in accordance } \\
\text { with what the farmer } \\
\text { wants! }\end{array}$ & $81 \%$ & Agree \\
\hline
\end{tabular}

\section{Discussion}

Based on the functionality test shown by the questionnaire's answer, the entire menu can work properly according to its function. The sample form of the application information system of rice milling places in Malind district based on the website has a home 
appearance that is quite attractive because it is designed with colors that are quite comfortable to see in Fig 3. The application user, in this case the patient, can select and get information about milling simply by selecting markers on the map on the main page for farmers as shown in Fig 4. Farmers and milling can see evidence of the results of transactions that have been carried out as shown in Fig 5. The results of the assessment obtained through the questionnaire can be said to be good as shown by the grinding statement presentation graph in Fig 6 and the arrangement of the farmer in Fig 7.

\section{Conclusion}

Based on the results of the application user questionnaire distributed to rice milling owners as many as fourteen people and seventy people, 10 people each were taken randomly from eight villages in the Malind District namely Kumbe, Rawasari, Kaiburse, Padang Raharja, Onggari, Sukamaju, Domande, and Malind, shows that the application of the milling information system has benefits for farmers in seeking and obtaining information, as well as being a better alternative business management system for rice mills.

\section{References}

1. M. Pertanian, PELARANGAN PENGGUNAAN BAHAN KIMIA BERBAHAYA PADA PROSES PENGGILINGAN PADI, HULLER DAN PENYOSOHAN BERAS. (2007).

2. J. Rehal, G. J. Kaur, and A. K. Singh, "Influence of Milling Parameters on Head Rice Recovery: A Review," Int. J. Curr. Microbiol. Appl. Sci., vol. 6, no. $10, \quad$ pp. 1278-1295, (2017), doi: 10.20546/ijcmas.2017.610.152.

3. RI, PERUSAHAAN PENGGILINGAN PADI, HULLER DAN PENYOSOHAN BERAS, vol. 65, no. 1. (1971).

4. H. A. A. Goda and I. L. Abd Elmagid, "Future of the news function of printed press under the competition of electronic communications: a prospective study in the period 2015-2025," Int. J. Commun. Soc., vol. 1, no. 2, pp. 58-67, (2019), doi: 10.31763/ijcs.v1i2.41.

5. N., A. Ibrahim, and A. Ambarita, "Sistem Informasi Pengaduan Pelanggan Air Berbasis Website Pada Pdam Kota Ternate," IJIS - Indones. J. Inf. Syst., vol. 3, no. 1, (2018), doi: 10.36549/ijis.v3i1.37.

6. RI, Uu-2008-11 Informasi Dan Transaksi Elektronik, vol. 11. (2008).

7. K. M. Bupati, Panduan Teknis Penyelenggaraan Pengendalian Intern Pemerintah di Lingkungan Pemerintah Kabupaten Merauke, vol. 6, no. 1. (2018).

8. Q. Yuni and F. Gita, "Transformation of Print Media in the Digital Era: Media Convergence of Kedaulatan Rakyat," Int. J. Commun. Soc., vol. 3, no. 1, pp. 27-38, (2021).
9. G. J. Maulany, S. Hence, and D. Loppies, "PUBLIC SERVICE INFORMATION SYSTEM FOR INTEGRATED POLICE SERVICE CENTERS IN," vol. 9, no. 12, pp. 220-229, (2018).

10. M. Manuhutu and J. Wattimena, "Perancangan Sistem Informasi Konsultasi Akademik Berbasis Website," J. Sist. Inf. Bisnis, vol. 9, no. 2, p. 149, (2019), doi: 10.21456/vol9iss2pp149-156.

11. M. N. K. Boulos, "Web GIS in practice III: Creating a simple interactive map of England's Strategic Health Authorities using Google Maps API, Google Earth KML, and MSN Virtual Earth Map Control," Int. J. Health Geogr., vol. 4, pp. 1-8, (2005), doi: 10.1186/1476-072X-4-22.

12. L. Penelitian and P. Masyarakat, "Prosiding," in Konferensi Nasional Sistem Informasi, (2016), p. 212.

13. H. Taherdoost, "What Is the Best Response Scale for Survey and Questionnaire Design: Review of Different Lengths of Rating Scale/Attitude Scale/Likert Scale," Int. J. Acad. Res. Manag., vol. 8, no. 1, pp. 2296-1747, (2019). 